\title{
The effect of quality of electronic banking services on agility of a bank
}

\author{
Hooman Pourmohammad*, Mostafa Zandieh and Hasan Farsijani
}

Faculty of Management and Accounting, Department of Industrial Management, Shahid Beheshti University, G.C., Tehran, Iran

\section{H R O N I C L E}

Article history:

Received June 5, 2015

Received in revised format

October 1, 2015

Accepted October 7, 2015

Available online

October, 2015

Keywords:

Banking services quality

Electronic banking system

Bank's agility

Service system quality

Personnel behavior quality

\section{A B S T R A C T}

Studies have shown that in service organizations, quality can have a growth in customer satisfaction as its consequence, and when it regards the banking services, factors are brought up with regard to the quality of banking services, which include the speed in responding, providing products proportionate to the customer needs, and gaining competence. These concepts are shared by the issue of organizational agility; hence, the qualities as well as the bank's agility of the banking system embrace these concepts in common. Therefore, the study aims at studying the effect of the quality of electronic banking services on the bank's agility, and assesses the role of two mediator variables of the quality of service system and personnel behavior quality. Using a questionnaire comprised of 76 items about the above components and asking the line personnel in Bank Saderat Iran (BSI) in the branches both inside and outside of Iran, the research data was collected, and stratified random sampling was used. To analyze the data, the Structural Equation Model (SEM) was used and the PLS software was employed to perform the computations. Results indicated that the model of the study has a high Goodness of Fit, and the quality of the electronic banking services had a significant effect on the bank's agility. In addition, the quality of electronic banking services affects the service system quality. The system service quality, also affects the employees' behavior. Therefore, it can be said that the electronic services quality and the bank's agility affect the personnel behavior quality through the mediated effect of the service system quality. The results of the present study can help the bank's executives to promote their bank's agility and the personnel behavior quality.

\section{Introduction}

In the today's competitive atmosphere, service organizations have noticed that in order to keep their customers and gain competitive advantage, an important issue that needs to be kept into consideration is improving the quality of services (Aneesh et al., 2014: 774). Quality of services will result in customer satisfaction and has a balance in the rate of keeping customers and as a result a larger share of market as its consequence (Gunarathne, 2014; Pourhasomi et al., 2013). 
Studies have shown that customer satisfaction and fulfillment is the most important issue in gaining competitive advantage for companies. Especially, service marketers are constantly seeking to develop strategies to offer high quality services and consequently achieve customer satisfaction (Afshar Jahanshahi et al., 2011, p. 254). Numerous researchers have pointed out that goods quality is one of the most important effective factors in customer satisfaction which is affected by marketing activities in service institutions especially banks, and is influenced by different variables like human factors, physical appearance, different systems for providing the services and so on (Quyet et al., 2015: 200; Phan \& Nham, 2015; Sureshchandar et al., 2002; Cheserek et al., 2015; Munir \& Rahman, 2015). Quality of services, especially with regard to banking systems, where getting distinguished from competitors is rather difficult, gains more importance since the quality of services has a considerable impact on customer satisfaction (Cheserek et al., 2015; Sakhaei et al., 2014). Studies have shown that if costumers are satisfied, they are more likely to use the banking services, which can result in more word of mouth advertisement. Hence, obtaining their satisfaction, customers can turn into advertisers for the bank (Pourkiani et al., 2014). In addition, creating a high level of service quality brings the satisfaction and loyalty of the customers, which in turn, results in an increase in market share and making profits by service organization especially banks (Kazemi et al., 2013).

Considering these issues, it can be said that quality of services is regarded as a factor in creating competitive advantage and can make the bank stand out in a way that the bank's distinguished status becomes very difficult or impossible for rival banks to achieve (Saghier \& Nathan, 2013:5). Hence, given the intangible feature of services especially banking services, it is imperative that some ways be found to assess the quality of services in order to be able to help the banks to enhance their quality of services and consequently have a more successful presence in the market (Igaz \& Ali, 2013).

Today, technology has had a great impact on the development of service delivery alternatives (Dabholkar \& Bagozzi, 2002 cited in Al-Hawari, et al., 2005) and a deep effect on service marketing. In order to keep their competitive capacity, banks are boosting their technology based service alternative (Fitzsimmons \& Fitzsimmons 1997). More and more banks have adopted technology to provide their customers with services and this has resulted in: reduced costs, the creation of value added services for customers (Zhu et al. 2002 cited in Al-Hawari, et al., 2005), the acceleration of their employees' jobs and ultimately, and the provision of self-service options for customers (Dabholkar \& Bagozzi, 2002, as cited in Al-Hawari, et al., 2005).

Hence, given the opportunities which new technologies offer to service organizations, it can be said that knowing about the customers' needs and demands, those organizations are successful which have the capability to respond to these needs, using new technologies (Madadipouya, 2015). This approach has given rise to a new concept in the area of business referred to as agility (Sajdak, 2013). An agile organization is the one which responds to the contextual settings and market needs quickly (Abesi et al., 2013; Dalvi et al., 2013). An agile organization enjoys high flexibility, which prepares the organization for any changes that the management is willing to make in order to gain competitive advantage (Christopher, 2000:37).

In banking, agility means speed in offering banking services according to market needs, offering new services, and flexibility based on intelligence (Asgari et al., 2014; Fendereski et al., 2014). In banking, agility can be regarded as enabling the personnel in responding appropriately to customers, predicting their needs and fulfilling those needs, and continuous novelty in offering new services (Asgari et al., 2014). Rapid changes in new banking technologies, a rise in the variety of demands, the customers' banking needs, and a decrease in the costs of the customer attrition, have made movement towards agile banking a requirement for banks. In an agile bank, raising the quality of the customers services can be expected, which accompanied by a higher speed, is an increase in the number of new services and a rise in the degree of keeping the existing customers and attracting new customers (Chamanifard et al., 2015). 
It can be said that one of the fundamental concepts in agility is an increase in the performance of the organization's activities, but a problem which some organizations face is that their over-attendance to agility sometimes inflicts mistakes like ignoring the quality of services on them. Hence, it is imperative that agility be created considering quality of services (Mahmoudi Maymand et al., 2015). Different studies have been conducted on agility and its relationship with organizational variables including business intelligence, organizational culture, work force, customer, organizational abilities and Personnel competences (Porkiani \& Hejinpoor, 2013; Sheikh Mahmoudi \& Asgari, 2013; Wendler, 2013). However, not many studies have been conducted regarding the relationship between quality of services and agility in the banking industry. Hence, the present study is seeking to address the issue of the effect of quality of services of the electronic banking on the agility of banking services as well as the role of the quality of service systems and behavior quality of the staff in the relationship between the above factors.

\section{Literature review}

Quality is a broad concept which has been defined differently from various perspectives. However, a perspective which according to the viewpoint of this study can provide a better definition of quality compared to other definitions is that quality is what the customers want. Especially when the issue of services is raised, due to the intangible nature of services, quality can be defined as what customers perceive of services. However, when measurement is involved, it should be noted that measuring the quality of services creates serious challenges for organizations, given measuring the quality of services is highly difficult (Prasad \& Jha, 2013). Owing to the difficulty of measuring the quality of services and the noticeable role of perception regarding services, researchers have brought up various aspects regarding quality measurement. For instance, some has regarded it as technical quality of output (Saldana et al., 2014, p. 159), or the quality of the process of the service offer, or a mental image of the organization providing the service (Nikzat et al., 2014: 3820). According to Parasuraman et al. (1991), aspects which can be used to measure the quality of services including reliability, true response, competence, availability, security, the reliability of the service provider, and customer communication and perception (Prasad \& Jha, 2013). Table 1 to 4 summarizes different definitions of the determining factors in quality of services presented by different scholars at the abstract (level 1) and concrete (level 2) levels. Features of the services are pigeonholed in Table 1.

\section{Table 1}

Factors related to the features of service at abstract and concrete levels

\begin{tabular}{ll}
\hline \multicolumn{1}{l}{ First level } & Second level \\
\hline & 1-Performance (Oort, 2014) \\
$\begin{array}{l}\text { 1. Reliability (Yarimoglu, 2014; } \\
\text { Patidar et al., 2014) }\end{array}$ & $\begin{array}{l}\text { 2-Accuracy (Yaghubi \& Seyedin, 2015:40) } \\
\text { 3- Consistency (Yarimoglu, 2014: 83) } \\
\text { 4-Fulfillment(Yaghubi \& Seyedin, 2015:40) }\end{array}$ \\
\hline & $\begin{array}{l}\text { 1- Safety ( Yaghubi \& Seyedin, 2015:40) } \\
\text { 2. Security (Yu et al., 2013) } \\
\text { confidentiality(Yarimoglu, 2014: 83) }\end{array}$ \\
\hline 3. tangibles (Moon, 2013: 91-92) & $\begin{array}{l}\text { 1-physical evidence and representations of the service, customers in service } \\
\text { facility(Yarimoglu, 2014: 83) }\end{array}$ \\
\hline 4. Price (Amiruddin, 2013; Buell et al., \\
2016)
\end{tabular}

Factors which are related to the personnel manner include responsiveness, courtesy and respect and competence of providers. The factors have been taken into consideration in the related studies. These features are tabulated in Table 2. 
Table 2

Factors related to personnel behaviors at abstract and concrete levels

\begin{tabular}{|c|c|}
\hline First level & Second level \\
\hline \multirow{4}{*}{$\begin{array}{l}\text { 1. Responsiveness } \\
\text { (Cheserek et al., 2015) }\end{array}$} & 1-timeliness of service(Yarimoglu, 2014: 83) \\
\hline & 2-calling the customer back quickly(Yarimoglu, 2014: 83) \\
\hline & 3-giving prompt service(Yarimoglu, 2014: 83) \\
\hline & 4- Convenience) Ivanauskiene \& Volungenaite, 2014: 119) \\
\hline $\begin{array}{l}\text { 2. Courtesy and respect (Saghier \& } \\
\text { Nathan, 2013; Timothy \& Abubakar, } \\
\text { 2013) }\end{array}$ & $\begin{array}{l}\text { politeness, respect, consideration, friendliness of contact personnel, } \\
\text { consideration for the consumer's property, clean and neat appearance of public } \\
\text { contact personnel (Yarimoglu, 2014: 83) }\end{array}$ \\
\hline \multirow{2}{*}{$\begin{array}{l}\text { 3. competence of providers (Ihtiyar et } \\
\text { al., 2014) }\end{array}$} & 1-Skills of personnel (Yarimoglu, 2014: 83) \\
\hline & 2-Knowledge of personnel (Yarimoglu, 2014: 83) \\
\hline
\end{tabular}

Organizational features related to services include availability, assurance and creditability, perceived Flexibility and Efficiency. These features are summarized into Table 3.

Table 3

Factors related to the organization providing the service at the abstract and concrete levels

\begin{tabular}{|c|c|}
\hline First level & Second level \\
\hline \multirow{4}{*}{ 1. availability (Al-Ababneh, 2013:166) } & 1- Appropriately and easy to use (Bhattacharya et al., 2012; Yarimoglu, 2014: 83) \\
\hline & 2-easily accessible (Yarimoglu, 2014: 83) \\
\hline & 3-Availibility in right time (Zhang, 2013) \\
\hline & 4-Convenient location of service facility(Yarimoglu, 2014: 83) \\
\hline $\begin{array}{l}\text { 2. Assurance and Creditability (Amiruddin, } \\
\text { 2013) }\end{array}$ & $\begin{array}{l}\text { 1- Trustworthiness, believability, honesty, Reputation in providing services, having the customer's } \\
\text { best interests at heart, personal characteristics of the contact personnel (Yarimoglu, 2014: 83) }\end{array}$ \\
\hline $\begin{array}{l}\text { 3. Perceived Flexibility (Salamzadeh \& } \\
\text { Mohammad Zadeh., (2015:54) }\end{array}$ & 1-Volume and Service provided, -Speed of Service( (Salamzadeh \& Mohammad Zadeh., 2015:54) \\
\hline \multirow{2}{*}{$\begin{array}{l}\text { 4. Efficiency(Yaghubi \& Seyedin, } \\
\text { 2015:40) }\end{array}$} & 1-Speed (Yaghubi \& Seyedin , 2015:40) \\
\hline & 2-Help customers ( Yaghubi \& Seyedin, 2015:40) \\
\hline
\end{tabular}

The manner of establishing relationship with customer and understanding their demands is considered another responsibility that occupies first and second levels of importance as shown in Table 4.

\section{Table 4}

Factors related to communications with customers at abstract and concrete levels

\begin{tabular}{ll}
\hline First level & Second level \\
\hline 1. communication(Mosadeghrad, 2014:214) & $\begin{array}{l}\text { 1-Keeping customers informed in language they can understand and listening to } \\
\text { 2-explaining the service itself and its cost(Yarimoglu, 2014: 83) } \\
\text { 3-assuring the consumer that a problem will be handled(Yarimoglu, 2014: 83) }\end{array}$ \\
\hline $\begin{array}{l}\text { 2. understanding/knowing the customer } \\
\text { (Salamzadeh \& Mohammad Zadeh, 2015:54) }\end{array}$ & $\begin{array}{l}\text { 1-understanding customer needs, learning the customer's specific requirements, } \\
\text { providing individualized attention, recognizing the regular customer(Yarimoglu, } \\
\text { 2014: 83) }\end{array}$ \\
\hline
\end{tabular}

\section{Quality of banking services}

Numerous studies have addressed service organizations and quality of services, and researchers have stressed that banking services should be distinguished from other services. In particular, some others have described the changes in customer expectations and different banking systems as too much, and have considered the necessity of flexibility in banks as a key factor for their survival (Wulandari \& Subajio, 2015; Okoe et al., 2013). Some authors, too, have pointed to optimizing the quality of banking services, and attending to customer satisfaction (Ghaffari Ashtiani \& Asgari Novin, 2013; Saeed et al., 2013) and their expectations (Kariru \& Allo, 2014), as well as consequences like profitability (Pakdil \& Kurtulmusoglu, 2014: 388-389). We can also refer to studies which have focused on diversity of 
services, congruence with the demands of the customers and linking quality with customer needs to gain competitive advantage (Warraich et al., 2013; ؛ Mozaffari Nejad, 2015; Jelcic, 2014:182).

With regard to measuring the quality of services, in addition to Fick \& Ritchie's (1991) view, the Servqual scale has been used to measure the perception of quality of services among several service industries. Later, authors like Zhu et al. (2002) and other researchers have applied this model or its moderated models to measure quality of banking services (Shlash Mohammad \& Mohammad Alhamadani, 2011; Uddin \& Akhter, 2012). Table 5 mentions the researchers who have undertaken measuring the quality of banking services. The authors and aspects which they have used to measure quality of banking services are also presented in the Table5.

\section{Table 5}

The models of the perceived quality of banking services

\begin{tabular}{|c|c|c|}
\hline & Researchers & Aspects \\
\hline 1 & Bahia and Nantel (2000) & Effectiveness and assurance, access, price, tangibles, service portfolio, Reliability \\
\hline 2 & Amin and Isa (2008: 194) & Tangibles, Reliability, Responsiveness, Assurance, Empathy \\
\hline 3 & Amiri Aghdaie and Faghani (2012:354) & Tangibles, Reliability, Responsiveness, Assurance, Empathy \\
\hline 4 & Beheshti Zavareh et al. (2012:444) & $\begin{array}{l}\text { Efficient and reliable Services, Fulfilment, Security/trust, Site Aesthetic, } \\
\text { Responsiveness/contact, Ease of use }\end{array}$ \\
\hline 5 & Shanka (2012:5) & Tangibility, Reliability, Responsiveness, Assurance, Empathy \\
\hline 6 & Talib et al. (2012: 2$)$ & $\begin{array}{l}\text { Customer service quality, Banking service product quality, Online/e-service } \\
\text { quality, Automated service quality }\end{array}$ \\
\hline 7 & Akbari and Darabi(2014:3) & $\begin{array}{l}\text { Physical dimensions and appearance, Reliability, Responsibility, Assurance, } \\
\text { Empathy }\end{array}$ \\
\hline 8 & Akhtar and Zaheer (2014) & $\begin{array}{l}\text { Tangibility, Reliability, Responsiveness, Assurance, Empathy, Customer } \\
\text { satisfaction }\end{array}$ \\
\hline 9 & Aliyu et al. (2014:563-564) & Cost, Security, Convenience \\
\hline 10 & Debasish and Sarma (2014) & $\begin{array}{l}\text { Tangibility, Reliability, Responsiveness, Assurance, Empathy, Timelines, } \\
\text { Friendliness }\end{array}$ \\
\hline 11 & Cudjoe et al. (2015:133) & Reliability, Responsiveness, Assurance, Empathy, Tangibility \\
\hline 12 & Dahari et al. (2015:25) & Reliability, Tangibles, Rates and Charges, Bank-Cost. Relationship, Shariah \\
\hline 13 & Kaur and Kiran(2015:81) & $\begin{array}{l}\text { Convenient operating hours ,Safety of funds transfer on net ,Reasonable service } \\
\text { charges, ATM Services, Internet banking assistance ,Depository services, Credit } \\
\text { card Services, Debit card Services, Phone banking Facility, Other IT based services } \\
\text {,One stop banking ,Innovative services }\end{array}$ \\
\hline 14 & Yaghubi and Seyedin(2015: 40) & $\begin{array}{l}\text { Security, Reliability, Fulfilment, Efficiency, Information Availability, Outcome } \\
\text { Quality, System Integration, Technical Adequacy }\end{array}$ \\
\hline 15 & Jugurnath et al. (2016:8) & Tangibility, Reliability, Responsiveness, Assurance, Empathy \\
\hline 16 & Qwader(2016:69) & Domains of confidentiality, quick response, competency \\
\hline 17 & Rostami et al. (2016:450-451) & $\begin{array}{l}\text { Efficiency, System availability, Implementation of commitments, Privacy Policy, } \\
\text { Response, Contact }\end{array}$ \\
\hline
\end{tabular}

Different models for quality of banking services have been referred to in different studies, and each of these models have discussed some aspects for measuring these kinds of services. One of such models is System and Transactional SQ scale (SYSTRA-SQ) which has been offered by Aldlaigan and Buttle (2002) and includes the quality of the service system, the behavior quality of service providers, exchange accuracy of services, and quality of machine services in the bank. Another model is Hierarchical Service Quality Model (HSQM) which was presented by Brady and Cronin (2001). Aspects of this model include the quality of interaction with customer, the quality of physical environment and the quality of output.

\section{Agility in banking systems}

In defining the concept of agility, Goldman et al. (1995) pointed to assigning a higher value to the customer, readiness for changes, valuing the personnel's knowledge and skills and forming virtual institutions (Jassbi et al., 2014; Sazesh \& Siadat, 2015). Other researchers point out that agility includes two basic principles: 1 - responding appropriately and timely to changes (predictable or unpredictable) 2- using the changes and viewing a change as an opportunity (Dehaghi et al., 2014; Dove, 2014; Shaarabh et al., 2014). Different studies have referred to key aspects of agility. These factors include responding to a change and lack of assurance (Sanadgol, 2014), creating basic competences (Taleghani 
et al., 2014), providing totally customized products or services (Sukati et al., 2014), combining different technologies (Seyed Hosseini \& Keyghobadi, 2014), and intra-organizational integrity (Landaran et al., 2014; Torkiyan et al., 2014).

Considering the above arguments, as service organizations, banks highly need agile structures to survive. The following can be mentioned as reasons for this:

1- Globalization of the banking services market (Mollazade \& Shahrokhi Dehkordi, 2015; Torkiyan et al., 2014).

2- The customers' need for a diversity of services (Torkiyan et al., 2014)

3- The customers' demands for fulfillment of their requests individually or customizing the banking services (Yarimoglu, 2014: 83)

4- The need for introducing new services and the banks' focusing on their marketing (Dalvi, 2013)

5- Having a broad range of services (Abesi et al., 2013)

Research objectives and focus issues: The main objective of this study is to recognize the effects of quality of electronic banking services on agility of the bank while considering the role of quality of service system and quality of personnel behavior. This case attempts to seek answers to the following questions:

1- What is the effect of electronic banking services on the perception of the service system?

2- What is the effect of the quality of services on the agility of banks?

3- What is the effect of the quality of the service systems on the behavioral quality of the providers of banking systems?

4- What is the relationship between the agility of a bank and the quality of the service system?

5- What is the relationship between the agility of a bank and the behavioral quality of the providers of the banking services?

Considering the relevant literature and the background of the study, it is expected that the relationship and effectiveness of the research variables presented in the above questions be according to Fig. 1.

\section{Materials and Methods}

Questionnaire design and pre-testing: The respondents were asked to evaluate the quality of behavior of personnel who offered banking service(BSQ), Machines used for banking service(MSQ ${ }^{1}$ ), Electronic banking service(ESQ), Transactional quality(TSA), Quality of service system(SSQ) and Agility of banking services(ASQ). Perceived service quality of each variable was measured through questions designed on a 5 point Likert-type scale ranging from Strongly Agree (as the best positive response) to Strongly Disagree(as the worst negative response). Any other response can be recorded between "Strongly Agree" and "Strongly Disagree" on the scale. After designing the questionnaire it was pretested with 30 respondents. The required changes were incorporated and the survey was conducted.

Sample characteristics: The line personnel of Bank Saderat Iran (BSI) in all of 2100 domestic branches and 22 branches in foreign countries considered for the study. The major reason to consider this bank is that this bank is private and it is working in the competitive context, both in domestic and foreign markets. Also the respondents and their behavior effects on customer's perception of service quality and line personnel can understand the customer's needs based on their direct relationship with them. The sample size of the research includes 380respondents that were selected based on a stratified random sampling method.

To assess the reliability of the questionnaire used in the present study, the Chronbach's alpha was used which indicated an appropriate reliability for the questionnaire. To ensure the validity of the

\footnotetext{
${ }^{1}$ Machine Service Quality
} 
questionnaire the AVE (Average Variable Extracted) was used, and an AVE higher than 0.5 was obtained, which according to Fornel and Larcker (1981) can be regarded as an indication of the validity of the test. In addition, face validity was determined with the help of experts and the validity of the data collection instrument was ensured. To analyze the data from the questionnaires the Structural Equation Models (SEM) and factor analysis were used. The Smart PLS software was used to do the above analyses.

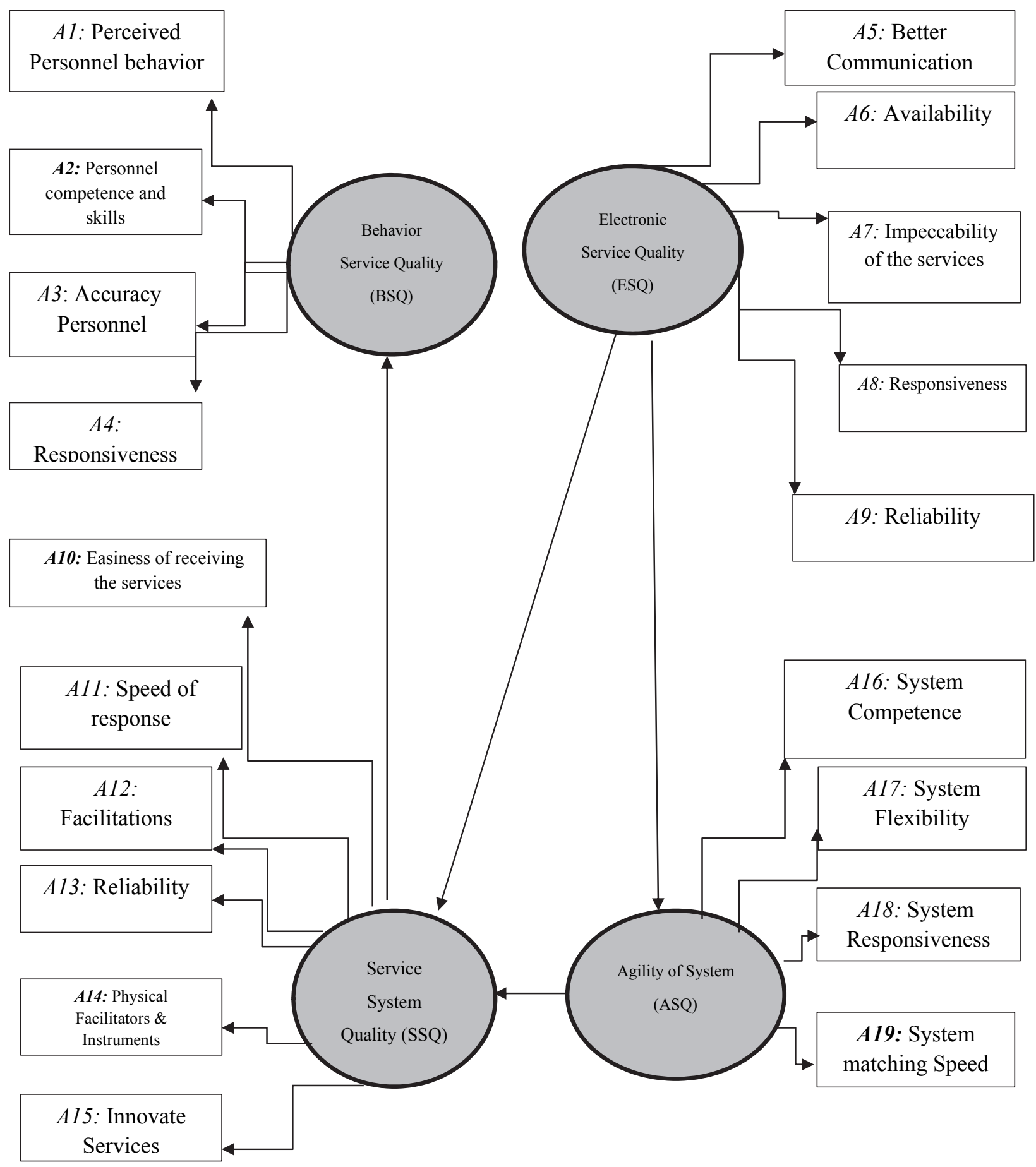

Fig. 1. Conceptual model: the relationship between the quality of electronic services and the agility of the bank 


\section{Results}

Using structural equations and the Smart PLS software, the respective model in the present study was tested. Criteria which indicate the reliability of the model are mentioned first, and then the answers to the research questions are provided.

1- The $\mathrm{R}^{2}$ scale: assesses the effect of the endogenous variables on the exogenous variables. The greater the amount of the $\mathrm{R}^{2}$ of the exogenous constructs of a model, the better the fitness of the model. Amounts larger than 0.67 show a strong effect. Considering this, it can be seen in Table 6 that the model has a good fitness.

Table 6

$\mathrm{R}^{2}$ values

\begin{tabular}{llllllllll}
\hline & R Sauare & & R Sauare & & R Sauare & & R Sauare & \multicolumn{2}{c}{ R Sauare } \\
\hline A1 & 0.961499 & A13 & 0.958623 & A17 & 0.822631 & A3 & 0.935880 & A7 & 0.919217 \\
A10 & 0.940717 & A14 & 0.971249 & A18 & 0.755395 & A4 & 0.959084 & A8 & 0.880682 \\
A11 & 0.941309 & A15 & 0.983492 & A19 & 0.768231 & A5 & 0.797810 & A9 & 0.867936 \\
A12 & 0.946849 & A16 & 0.734691 & A2 & 0.949228 & A6 & 0.921821 & & \\
\hline
\end{tabular}

2- The effect size scale (F2): this scale determines the intensity of the relationship between the constructs of the model, which if larger than 0.35 indicates a relationship between the constructs of the model. Considering the values on the line in Fig. 2, it can be observed that all of them are larger than 0.35 , and it can be said that there is a strong relationship between the constructs of the model.

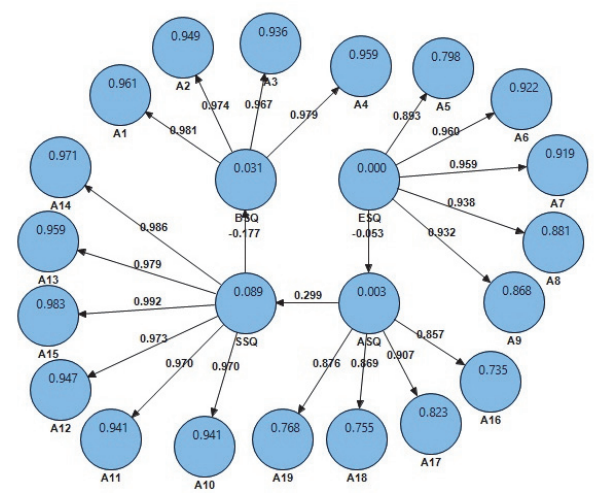

Fig. 2. Effect size

3- The Q2 scale: This investigates the predictability of the latent exogenous variables in the models and shows the fitness and interactional validity of the model. Values larger than 0.35 show strong prediction. As can be seen in Table 7, there is a strong prediction.

Table 7

Q2 values

\begin{tabular}{llllllllll}
\hline Total & Q2 & Total & Q2 & Total & Q2 & Total & Q2 & Total & Q2 \\
\hline A1 & 0.824732 & A13 & 0.838143 & A17 & 0.478251 & A3 & 0.861357 & A7 & 0.666722 \\
A10 & 0.830505 & A14 & 0.840743 & A18 & 0.442712 & A4 & 0.844681 & A8 & 0.667961 \\
A11 & 0.829263 & A15 & 0.839441 & A19 & 0.480283 & A5 & 0.673641 & A9 & 0.666670 \\
A12 & 0.837439 & A16 & 0.431205 & A2 & 0.836236 & A6 & 0.697860 & A7 & 0.666722 \\
ASQ & 0.001024 & BSQ & 0.026002 & SSQ & 0.089978 & & & & \\
\hline
\end{tabular}


4- The GOF scale (Goodness of fit): Based on this scale, the mean value of $\mathrm{R}^{2}$ and the communality for estimating GOF is applied according to the following formula (Wetzels et al., 2009). The value of GOF equals 0.762199 , and since it is larger than 0.36 , and it can be said that the model has a good fitness. Hence, a t-statistics was used to show the significance of the effect of each variable in the model.

$$
\mathrm{GOF}=\sqrt{0.778501696 \times 0.746238}=0.762199
$$

If the t-statistics is larger or smaller than -1.96 , it shows the significance of that variable on the variable which is located at the end of the arrow. Considering the value of $t$ for the main variables (construct) in the figure, it can be observed that all the $t$ values are larger than 1.96, and thus the relationships among the variables can be depicted like Fig. 3. The relations among the following variables are significant at .05 level:

1- Electronic services quality (ESQ) affects the service system (SSQ).

2- Electronic services quality (ESQ) affects the bank agility (ASQ).

3- Service system quality (SSQ) affects the behavior service quality (BSQ).

4- Agility services quality (ASQ) affects the system service quality (SSQ).

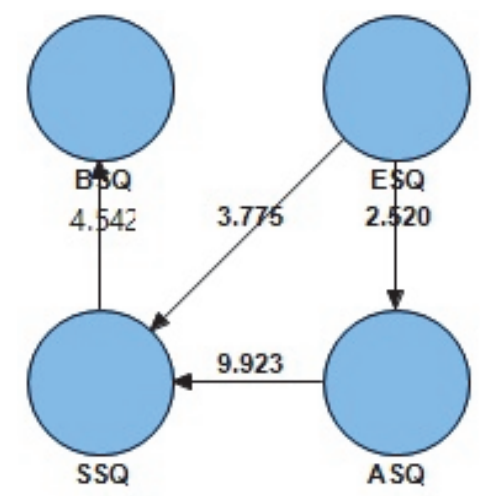

Fig. 3. t-statistics of the structural model

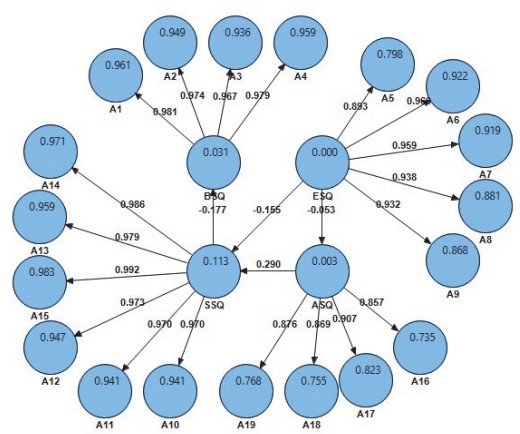

Fig. 4. The coefficients of the components related to each variable in the structural equations model

Considering the value of $t$ for the components related to the main variables which are all larger than 1.96 , it can said that all components related to the four main variables in the model are considered as significant, and judgments can be made based on the values for its factor loads. The values of the factor loads of all components related to the main research variables are presented in Fig. 4.

\section{Discussion and conclusion}

The conceptual model of the present study had high indices of goodness of fit which ensures the researcher of the high intensity of the relationship between the elements of the model. The results of the hypotheses tests, too, showed that if electronic banking services (ESQ) have high quality, they can result in a rise in the perception of the quality of the service system (SSQ). In other words, if easy communication, availability, responsiveness, reliability and flawlessness of the services occurs, this can result in a higher perception of innovation, the existence of physical facilities, better facilities, speed in responding to the customers, and the easiness of receiving the services. This conclusion is similar to Kaur and Kiran (2015) with regard to the effect of comfort, availability, security, and the interaction with the website, and the existence of the physical facilities like ATM on the perception of the quality of electronic services. Similar to the above conclusion, Akhtar and Zaheer (2014), too, showed that reliability and tangible elements affect the assessment of the quality of services and customer satisfaction. On the other hand, quality of electronic banking services (ESQ) can cause an 
improvement in the quality of agile banking systems (ASQ). More specifically, it can be said that if the ease of communication, availability, responsiveness, and the flawlessness of the services is enhanced in the bank, this causes a rise in indices like flexibility, the speed of adaptation, the banking system's responsiveness, and the competence of the system. Another finding of the present study is that the quality of agile banking systems (ASQ) can enhance the quality of the service system (SSQ), which if the minor components of the above factors are stated, it can be observed that an increase in scales like flexibility, the speed of adjustment, the responsiveness of the banking system, the system competence and result in a more perception of innovation, the existence of physical facilities, speed in responding to customers' needs and the ease in receiving the services.

In addition, a perception of the high quality of the service system (SSQ) results in a perception of the behavior quality of the service providers (BSQ). Separating the above factors into their specific components shows that the perception of innovation in banking systems, better facilities, speed in responding to customers, and the ease of receiving the services can result in the perceived personnel behavior, responsiveness to customers, personnel competence and skills, and personnel accuracy in providing the services. This is in line with Jabnoun and Al-Tamimi (2003) and Guo et al. (2001) with regard to personnel skills. With regard to the service system, personnel behavior, and the existence of physical machines and facilities of service providing, the present study is in line with Aldlaigan \& Buttle(2002) and Karatape et al(2005). The results are also in line with Sureshchandar et al. (2002). Moreover, the results are in line with Debasish and Sarma (2014) with regard to the effect of the variables of quality of services on the elements of responsiveness, the speed of responding to customers (i.e. timeliness) and friendliness. Given the similarities of the findings of the present study to many of previous studies, and analyzing the relationship between the latent variables in the structural model, it can be claimed that the quality of electronic services can affect the quality of the service system in two ways. The first is direct and the other is through the mediated effect on the banking system agility. The mediated effect is in a way that first, the electronic quality of the services causes agility in providing the services, and then through enhancing the agility, it causes a growth in the quality of the bank's service system. It can also be said that the only effective factor in the behavior quality of the personnel is the quality of the service system. In fact, it can be said that in a bank the behavior quality of services (BSI) is directly or indirectly affected by three factors: the electronic quality of services, the agility of the banking system, and the quality of service system. Another considerable point in the present study is that all of the elements of the four factors, which are referred to as latent variables in this study, became significant in the structural equations. This shows that finding these variables has been conducted with a thorough examination of the relevant aspects of the issue during the construction of questionnaire, and it has comprehensiveness.

The present study shows that the behavior quality of the services is affected by three factors, while it was expected that the banking system agility to be influenced by three other factors. It seems that the reason for this is that the cultural atmosphere of the bank BSI is in a way that the personnel first expect the quality of electronic services and service system and agility in banking system to be created, and then they raise their own behavior quality. It seems necessary for banks' managements create a cultural atmosphere for the personnel to know that changes should first arise in their job behaviors in order for the banking services systems gain agility. Other variables which were important in the present study, and have been referred to in previous studies were system flexibility, the speed of the service system adjustment, the speed in responding to customers, and responsiveness to customers. It is advised that banks' executives plan to enhance these variables. It is also advised that future studies apply these factors in order to assessing banks agility.

\section{Limitations and Caveats}

It should be noted that the findings of the present study are limited to BSI and the findings can only be generalized to the branches and personnel of this bank. In the present study, only the perception of the personnel from the agility and services of the BSI have been assessed. In addition, due to the existing 
limitations, the research population only included the bank's personnel, and it is better to ask the bank's customers, too, since competent customers conduct assessments of the quality of services. It is suggested that future studies on other banks study whether in other Iranian banks; too, the personnel behavior quality is more affected than other three factors. It is also advised that future studies conduct comparisons to see whether in other countries' banks, too, the behavior service quality is affected by other factors or the banking services agility is affected by other factors.

\section{References}

Abesi, S., Mohammadi, M., \& Shafieepur, D. (2013). The role of Organizational agility capabilities in the successful performance of the national production. World of Sciences Journal, 3, 17-32.

Jahanshani, A. A., Hajizadeh, G. M. A., Mirdhamadi, S. A., Nawaser, K., \& Khaksar, S. M. S. (2014). Study the effects of customer service and product quality on customer satisfaction and loyalty. International Journal of Humanities and Social Science, 1(7), 253-260.

Akbari, P., \& Darabi, A. (2015). Factors affecting customer satisfaction, quality banking services to Iran, using the SERVQUAL model case study: Resalat bank of Kermanshah province. Advanced Social Humanities and Management, 1(4), 1-5.

Akhtar, A., \& Zaheer, A. (2014). Service quality dimensions of Islamic banks: A scale development approach. Global Journal of Management And Business Research, 14(5), 11-20.

Alabar, T. T., \& Abubakar, H. S. (2013). Impact Of Employee Empowerment on Servic e Quality-An Empirical Analysis of The Nigerian Banking Industry.British Journal of Marketing Studies, 1(4), 32-40.

Al-Ababneh, M. (2013). Service quality and its impact on tourist satisfaction. Interdisciplinary Journal of Contemporary Research in Business, 4(12), 164-177.

Aldlaigan, A. H., \& Buttle, F. A. (2002). SYSTRA-SQ: a new measure of bank service quality. International Journal of Service Industry Management,13(4), 362-381.

Al-Hawari, M., Hartley, N., \& Ward, T. (2005). Measuring banks' automated service quality: a confirmatory factor analysis approach. Marketing bulletin,16(1), 1-19.

Aliyu, A. A., Rosmain, T., \& Takala, J. (2014). Online banking and customer service delivery in Malaysia: data screening and preliminary findings.Procedia-Social and Behavioral Sciences, 129, 562-570.

Amin, M., \& Isa, Z. (2008). An examination of the relationship between service quality perception and customer satisfaction: A SEM approach towards Malaysian Islamic banking. International Journal of Islamic and Middle Eastern Finance and Management, 1(3), 191-209.

Amiri Aghdaie, S. F., \& Faghani, F. (2012). Mobile banking service quality and customer satisfaction (application of SERVQUAL model). International Journal of Management and Business Research, 2(4), 351-361.

Amiruddin N. H. (2013). Price service quality and customer loyalty: A case of Air ASIA. South East Asia Journal of Contemporary Business, Economics and Law, 2(1), 34-40.

Aneesh, A., Dileeplal J., \& Abraham M. (2014). An integrated fuzzy weighted SERVQUAL-QFD approach for service quality improvement. International Journal of Engineering Research, 3(12), 774-776.

Asgari, H., Baziar, N., \& Maleki R. (2014). A study on relationship among organizational culture and organizational agility in Agri-bank at Khuzestan province. International Journal of Management and Humanity Sciences, 3(2), 1448-1458.

Bahia, K., \& Nantel, J. (2000). A reliable and valid measurement scale for the perceived service quality of banks. international journal of bank marketing, 18(2), 84-91.

Beheshti Zavareh, F., Ariff, M. S. M., Jusoh, A., Zakuan, N., Bahari, A. Z., \& Ashourian, M. (2012). E-service quality dimensions and their effects on e-customer satisfaction in internet banking services. Procedia-social and behavioral sciences, 40, 441-445.

Bhattacharya, D., Gulla, U., \& Gupta, M. P. (2012). E-service quality model for Indian government portals: citizens' perspective. Journal of Enterprise Information Management, 25(3), 246-271.

Buell, R. W., Campbell, D., \& Frei, F. X. (2014). How do customers respond to increased service quality competition?. Harvard Business School Accounting \& Management Unit Working Paper, (11-084), 11-084.

Chamanifard, R., Nikpour, A., Chamanifard, S., \& Nobarieidishe, S. (2015). Impact of organizational agility dimensions on employee's organizational commitment in foreign exchange offices of Tejarat Bank, Iran. European Online Journal of Natural and Social Sciences, 4(1), 199.

Cheserek L. K., Kimwolo A. K., \& Cherop F., (2015). Effect of quality financial services on customer satisfaction by commercial banks in Kenya. International Journal of Humanities and Social Science, 5(7), 102-112.

Christopher, M. (2000). The agile supply chain: competing in volatile markets. Industrial Marketing Management, 29(1), 37-44. 
Cudjoe A. G., Anim P. A., \& Tetteh Nyanyofio J. G. N., (2015)., Service quality and customer satisfaction in the Ghanaian banking industry (A case of Ghana commercial bank), European Journal of Business and Management, 7(3), 123-140.

Dahari, Z., Abduh, M., \& Fam, K. S. (2015). Measuring service quality in Islamic banking: Importance-performance analysis approach. Asian Journal of Business Research, 5(1), 15-28.

Dalvi M. R., Shekarchizadeh A. R., \& Rajaei Baghsorkhi G. (2013). Investigating of organizational agility components (innovation speed, accountability, integrated information systems, flexible and multi-skilled employees and flexibility) on the organizational performance based on the satellite model (snowa company as a case study). Global Journal of Pure \& Applied Science and Technology, 3(4), 1 - 14.

Debasish, S. S., \& Sarma S. (2014). A service quality assessment of banks with special reference to state bank of India (SBI) and HDFC Bank. Information and Knowledge Management, 4(1), 126-133.

Dehaghi, A. K., Navabakhsh, M., \& Ardestani, H. R. A. (2014). Study the effect of individual factors to implementing the agility strategy in Isfahan municipality. International Journal of Academic Research in Economics and Management Sciences, 3(1), 61.

Dove, R. (2014). Agile systems-engineering and agile-systems engineering. Insight: International Council on Systems Engineering, 17(2). 6-10.

Fendereski, A., Didehkhani, H., \& Fendereski, A. (2014). The identification and ranking of key factors related to organizational agility using analytic hierarchical processing. International Journal of Basic Sciences \& Applied Research, 3(7), 455-464.

Fick, G. R., \& Ritchie, J. B. (1991). Measuring service quality in the travel and tourism industry. Journal of Travel Research, 30(2), 2-9.

Ghaffari Ashtiani, P., \& Asgari Novin, M. (2013). Study of the effect of perceived service quality on customers' satisfaction, trust and loyalty using Servqual model (case study of saderat bank website users). International Journal of Advanced Studies in Humanities and Social Science, 1(7), 826-840.

Gunarathne, U. (2014). Relationship between service quality and customer satisfaction in Sri Lankan hotel industry. International Journal of Scientific and Research Publications, 4(11), 1-7.

Guo, X., Duff, A., \& Hair, M. (2008). Service quality measurement in the Chinese corporate banking market. International journal of bank marketing,26(5), 305-327.

Igaz, A. T., \& Ali, A. .(2013). Measuring banks service attitude: An approach to employee and customer acuities. Journal Of Business And Management, 7(2), 60-66.

Ihtiyar, A., Ahmad, F. S., \& Osman, M. H. M. (2014). An Integrated framework: Intercultural competence, service quality and customer satisfaction in grocery retailing. Procedia-Social and Behavioral Sciences,109, $492-496$.

Ivanauskienè, N., \& Volungènaite, J. (2014). Relations between service quality and customer loyalty: An empirical investigation of retail chain stores in emerging markets. American Journal of Social Science, 3(2), 113-120.

Jabnoun, N., \& Hassan Al-Tamimi, H. A. (2003). Measuring perceived service quality at UAE commercial banks. International Journal of Quality \& Reliability Management, 20(4), 458-472.

Jassbi, J., Pilevari, N., \& Garmaki M. (2014). Role of time in agile supply chain. International Journal of Industrial Engineering \& Production Research, 25(2), 115-124.

Jelcic, S. (2014). Managing service quality to gain competitive advantage in retail environment. TEM Journal, 3(2), 181-186.

Jugurnath, B., Nowbutsing, J., \& Ramen, M. (2016). The banking sector in mauritius:

An assessment of service quality from customer perspective. Proceedings of the International Conference on Tourism, Hospitality and Marketing, (IC16Mauritius Conference) ISBN - 978-1-943579-19-8., Ebene-Mauritius, 21-23 January, 2016. Paper ID: M624., pp 1-22.

Karatepe, O. M., Yavas, U., \& Babakus, E. (2005). Measuring service quality of banks: Scale development and validation. Journal of Retailing and Consumer Services, 12(5), 373-383.

Kariru, A. N., \& Aloo, C. (2014). Customers perceptions and expectations of service quality in hotels in western tourism circuit, Kenya. Journal of Research in Hospitality, Tourism and Culture, 2(1), 1-12.

Kaur, N., \& Kiran, R. (2015). E-banking service quality and customer loyalty: Changing dynamics of public, private and foreign bank consumers in India. Global Business \& Management Research, 7(1), 74-92.

Kazemi, M., \& Amini, A. (2013). Identify and ranking factors affecting bank maskan service quality using Kano model. Research Journal of Recent Sciences, 2(4), 11-19.

Landaran, S., Forghani, M. H., Hamidi, V., \& Dehaghi, M. R. (2014). Studying the relationship between organizational learning \& dimension of organizational agility: a case study-university of Isfahan. Journal of social issues \& humanities, 2, 146-151.

Madadipouya, K. (2015). A review on the strategic use of it applications in achieving and sustaining competitive advantage. International Journal of Managing Public Sector Information and Communication Technologies. 6(2), 21-30. 
Meymand, M. M., Vahdat, D., \& Nazari, S. A. (2015). Review of the effect of enterprise systems on agility in the organization. Technical Journal of Engineering and Applied Sciences, 5(S), 243-252.

Mollazade, M., \& Shahrokhi Dehkordi, M. S. (2015). Method to property the organizations based on their agility. Journal of Applied Environmental and Biological Sciences, 4(12S), 321-328.

Mosadeghrad A. M. (2014). Factors affecting medical service quality. Iranian Journal of Public Health, 43(2), $210-$ 220.

Moon, Y. J. (2013). The tangibility and intangibility of e-service quality. International Journal of Smart Home, 7(5), 91-102.

Mozaffari Nejhad, M. (2015). Gaining competitive advantage by innovation in different aspects of providing customer service. Journal of Applied Environmental and Biological Sciences, 5(10S), 590-594.

Munir, M.M.M., \& Rahman, M. (2015). E-banking service quality and customer satisfaction of a state owned schedule bank of Bangladesh. Journal of Internet Banking and Commerce, S2(9), 1-5.

Nikzat, P., Rezazadeh, B., \& Khodaparasti, R. B. Linking the three dimensional Service quality model to customer satisfaction and Loyalty. International Journal of Management and Humanity Sciences, 3(12), 3819-3831.

Okoe, A. F., Adjei, J. S., \& Osarenkhoe, A. (2013). Service quality in the banking sector in Ghana. International Journal of Marketing Studies, 5(2), 81-92.

van Oort, N. (2014). Incorporating service reliability in public transport design and performance requirements: International survey results and recommendations. Research in Transportation Economics, 48, 92-100.

Patidar, D. K., Sisodiya P. S., \& Saxena P., (2014). Have another look on service quality in the tractor industry service. International Journal of Research in Aeronautical and Mechanical Engineering, 2(7), 58-68.

Pakdil, F., Kurtulmuşoğlu, F. B., \& Yolu, E. (2014). Improving service quality in highway passenger transportation: a case study using quality function deployment. EJTIR, 14(4), 375-393.

Prasad, R. K., \& Kumar Jha, M. (2013). Quality measures in higher education: A review and conceptual model. Quest Journals, Journal of Research in Business and Management, 1(3), 23-40.

Phan, C. A., \& Nham, P. T. (2015). Impact of service quality on customer satisfaction of automated teller machine service: case study of a private commercial joint stock bank in Vietnam. Business: Theory and Practice/Verslas: Teorija ir Praktika, 16(3), 280-289.

Porkiani, M., \& Hejinipoor, M. (2013). Studying the relationship between organizational intelligence and organizational agility in supreme audit court.European Online Journal of Natural and Social Sciences, 2(3 (s)), pp-1052.

Pourhasomi, M., Khamseh, A., \& Ghorbanzad, Y. (2013). A hybrid of Kano and QFD for ranking customers' preferences: A case study of bank Melli Iran. Management Science Letters, 3(3), 845-860.

Pourkiani, M., Goudarzvand Chegini, M., Yousefi, S., \& Madahian S. (2014). The relationship between service quality with customer satisfaction and words of mouth (Case study: Iran Insurance branch, Guilan). International Journal of Management and Humanity Sciences, 3(6), 2340-2350.

Ghodrati, H., \& Taghizad, G. (2014). Service quality effect on satisfaction and word of mouth in insurance industry. Management Science Letters, 4(8), 1765-1772.

Van Quyet, T., Vinh, N. Q., \& Chang, T. (2015). Service quality effects on customer satisfaction in banking industry. International Journal of u-and e-Service, Science and Technology, 8(8), 199-206.

Qwader, A. (2016). Impact of the Quality of Banking Services for Plastic, Electronic Magnetic Cards on Customers Satisfaction and his Future-Purchasing Behavior: A Practical Study on A Number of Commercial Bank Customers in Amman. Asian Economic and Financial Review, 6(2), 66-82.

Rostami, A., Khani, A. H. A., \& Soltani, G. (2016). The Impact of E-service Quality on the Improvement of the Level of Communication with Customers of Bank Melli Branches in South Tehran Affairs Office. Procedia Economics and Finance, 36, 448-455..

Saeed, R., Safdar, M., Arshad, H. M., Ahmad, W., Khurshid, N., \& Lodhi, R.N. (2013). Service quality attributes and customer satisfaction: An empirical study on microfinance banks- A case from Pakistan. Journal of Basic and Applied Scientific Research, 3(6), 723-731.

El Saghier, N., \& Nathan, D. (2013, April). Service quality dimensions and customers' satisfactions of banks in Egypt. In Proceedings of 20th International Business Research Conference (pp. 4-5).

Sajdak, M. (2013). The influence of agility on creating a competitive advantage and on company performance.

Sakhaei, F., Afshari, A., \& Esmaili, E. (2014). The impact of service quality on customer satisfaction in Internet banking. Journal of mathematics and computer science, 9, 33-40.

Salamzadeh, Y., \& Zadeh, M. A. M. (2015). Investigating the quality of Service in chain stores using SERVQUAL approach (Case Study: Refah Stores on Alborz Province). Archives of Business Research, 3(6), 50-67.

Saldana, L. M., Encinas, V. G., \& Buron, A. S., (2014). The technical quality of the service provided by adventure companies in Spain, Italy and CostaRica., 9(1), 157-171.

Sanadgol, M. (2014). The survey of relationship between organizational agility and principals job satisfaction. International Journal of Basic Sciences \& Applied Research, 3, 317-319. 
Sazesh, A., \& Siadat, S. A. (2015). The relationship between quantum management and organizational agility in ministry of roads and urban development of Golestan province, Iran. International Research Journal of Management Sciences, 3, 28-31.

Seyedhosseini, S., \& Keyghobadi, A. (2014). An integrated model for mechatronic products in agile manufacturing system. Decision Science Letters, 3(4), 535-550.

Shaarabh, M., Rishi G., \& Sharma S.K. (2014). A review on measurement of agility. Industrial Engineering \& Management, 3(1), 1-4.

Shanka, M. S. (2012). Bank service quality, customer satisfaction and loyalty in Ethiopian banking sector. Journal of Business Administration and Management Sciences Research, 1(1), 1-9.

Sureshchandar, G. S., Rajendran, C., \& Anantharaman, R. N. (2002). Determinants of customer-perceived service quality: a confirmatory factor analysis approach. Journal of Services Marketing, 16(1), 9-34.

Mahmoudi, H. S., \& Asgari, M. H. (2013). Investigation of Relationship between Organizational Intelligence and Agility of High School Administrators in Mazandaran Province, Iran. International Research Journal of Applied and Basic Sciences, 5(7), 905-911.

Mohammad, A. A. S., \& Alhamadani, S. Y. M. (2011). Service quality perspectives and customer satisfaction in commercial banks working in Jordan. Middle Eastern Finance and Economics, 14(1), 60-72.

Sukati, I., Hamid, A. B., Baharun, R., \& Jamal, N. M. (2014). The Moderating Role of Market, Firm and Supply Chain Factors on the Relationship between Information Technology Practices and Supply Chain Agility. American Journal of Industrial and Business Management, 4, 258-266.,

Talib, F., \& Rahman, Z. (2012). Impact of total quality management and service quality in the banking sector. Journal of Telecommunications System \& Management, 1(2), 1-5.

Taleghani, G. R., Amirkhani, A. H., \& Froughi, H. (2014). Identify and prioritize the factors affecting the implementation of agile manufacturing (Case Study: Khui Sugar Factory). Journal of Novel Applied Sciences, 3(10), 1122-1124.

Torkiyan, K., Khorvash, M., \& Tabaeiyan, A. (2014). On the relationship of applying information technology with organizational agility in youth sports organizations of Esfahan province. International Journal of Sport Studies,4(12), 1546-1550.

Uddin, M. B., \& Akhter, B. (2012). Determinants of Customer Satisfaction of Banking Industry in Bangladesh. Pakistan Journal of Commercial Society of Science, 6(2), 242-256.

Warraich, K. M., Warraich, I. A., \& Asif, M. (2013). Achieving Sustainable Competitive Advantage through Service Quality: an Analysis of Pakistan's Telecom Sector. Global Journal of Management And Business Research,13(2), 39-46.

Wendler, R. (2013, September). The structure of agility from different perspectives. In Computer Science and Information Systems (FedCSIS), 2013 Federated Conference on (pp. 1177-1184). IEEE.

Wulandari, D., \& Subagio, A. (2015). Consumer decision making in conventional banks and Islamic bank based on quality of service perception. Procedia-Social and Behavioral Sciences, 211, 471-475.

Yaghubi N. M., Seyedin S. M., (2015)., Ranking the technical dimensions of e-banking service quality evaluation models using Analytical Hierarchy Process. ACSIJ Advances in Computer Science: an International Journal, 4(1), pp 37-43.

Yarimoglu, E. K. (2014). A review on dimensions of service quality models. Journal of Marketing Management, 2(2), 79-93.

Yu, F. R., Tang, H., Bu, S., \& Zheng, D. (2013). Security and quality of service (QoS) co-design in cooperative mobile ad hoc networks. EURASIP Journal on Wireless Communications and Networking, 1, 1-14.

Zhang, Y. (2013). Measuring service quality of online banking in China. Aalto University, MA, 2013.

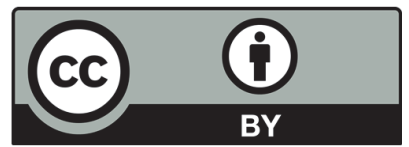

(C) 2016 by the authors; licensee Growing Science, Canada. This is an open access article distributed under the terms and conditions of the Creative Commons Attribution (CC-BY) license (http://creativecommons.org/licenses/by/4.0/). 